\title{
41SM150: A Middle Caddo Period Site in the Angelina River Basin, Smith County, Texas
}

Timothy K. Perttula

Heritage Research Center, Stephen F. Austin State University

Follow this and additional works at: https://scholarworks.sfasu.edu/ita

Part of the American Material Culture Commons, Archaeological Anthropology Commons, Environmental Studies Commons, Other American Studies Commons, Other Arts and Humanities Commons, Other History of Art, Architecture, and Archaeology Commons, and the United States History Commons

Tell us how this article helped you.

This Article is brought to you for free and open access by the Center for Regional Heritage Research at SFA ScholarWorks. It has been accepted for inclusion in Index of Texas Archaeology: Open Access Gray Literature from the Lone Star State by an authorized editor of SFA ScholarWorks. For more information, please contact cdsscholarworks@sfasu.edu. 
41SM150: A Middle Caddo Period Site in the Angelina River Basin, Smith County, Texas

\section{Creative Commons License}

\section{(c) (1) \&}

This work is licensed under a Creative Commons Attribution-NonCommercial 4.0 International License 


\section{SM150: A Middle Caddo Period Site in the Angelina River Basin, Smith County, Texas}

Timothy K. Perttula

\section{Introduction}

Site 41SM150 is an ancestral Caddo settlement and cemetery in the headwaters of the Angelina River basin in East Texas (Figure 1). The site was recorded by Jan Guy in 1983 as part of a University of Texas at Austin Field School, when a collector who was working at the site shared information about what he, and others, had been finding there. Apparently the site had been worked by collectors for approximately 30 years by that time. The current condition of the site is not known.

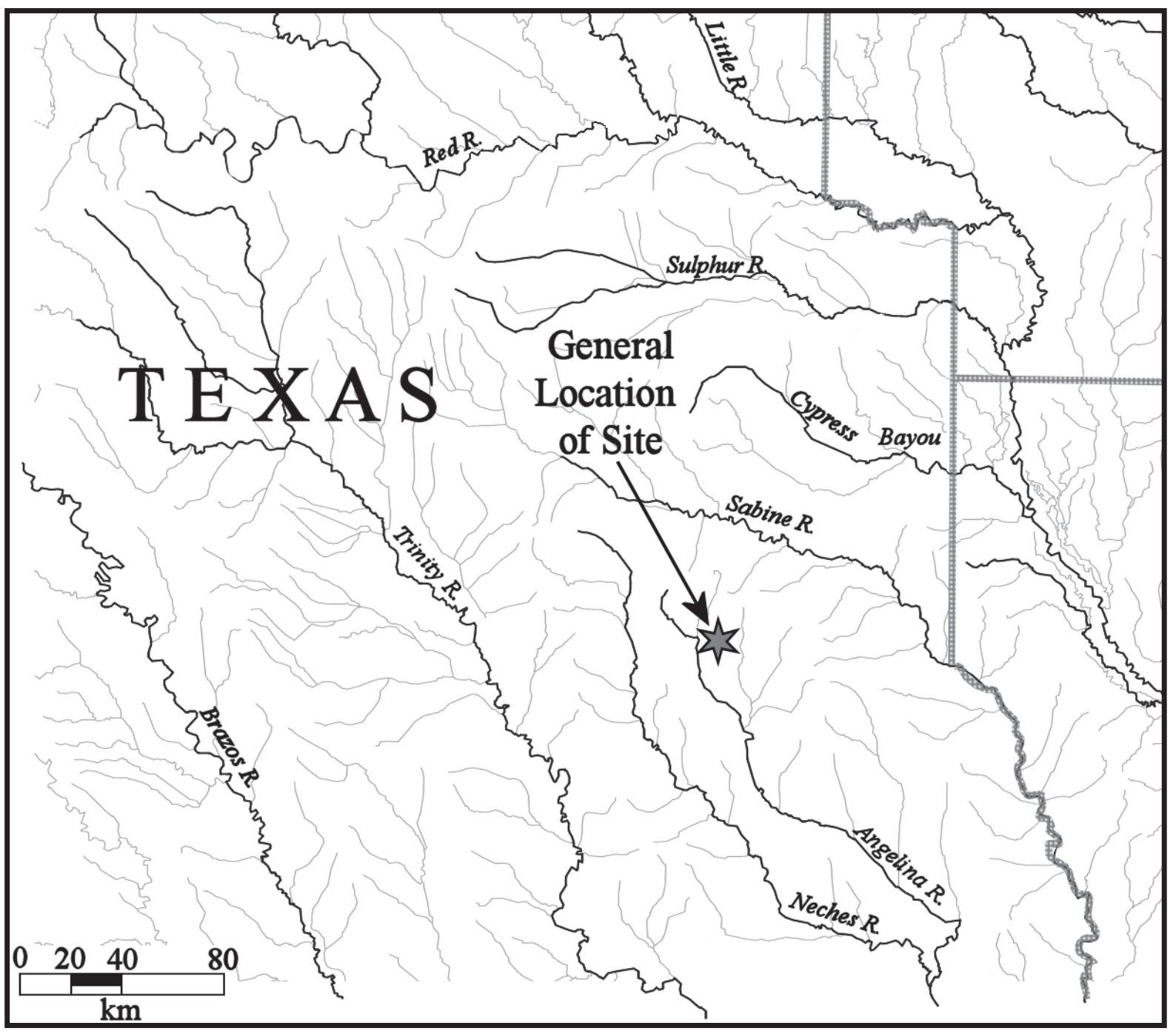

Figure 1. General location of 41SM150 in East Texas. 
The site, including both habitation and cemetery areas, is located just south of a large knoll on an alluvial terrace on the north side of the Kickapoo Creek valley (Figure 2). Kickapoo Creek is a westwardflowing tributary of Mud Creek in the Angelina River basin. The site area had been cultivated in the past, but in 1983 was overgrown, with weeds and pine trees.

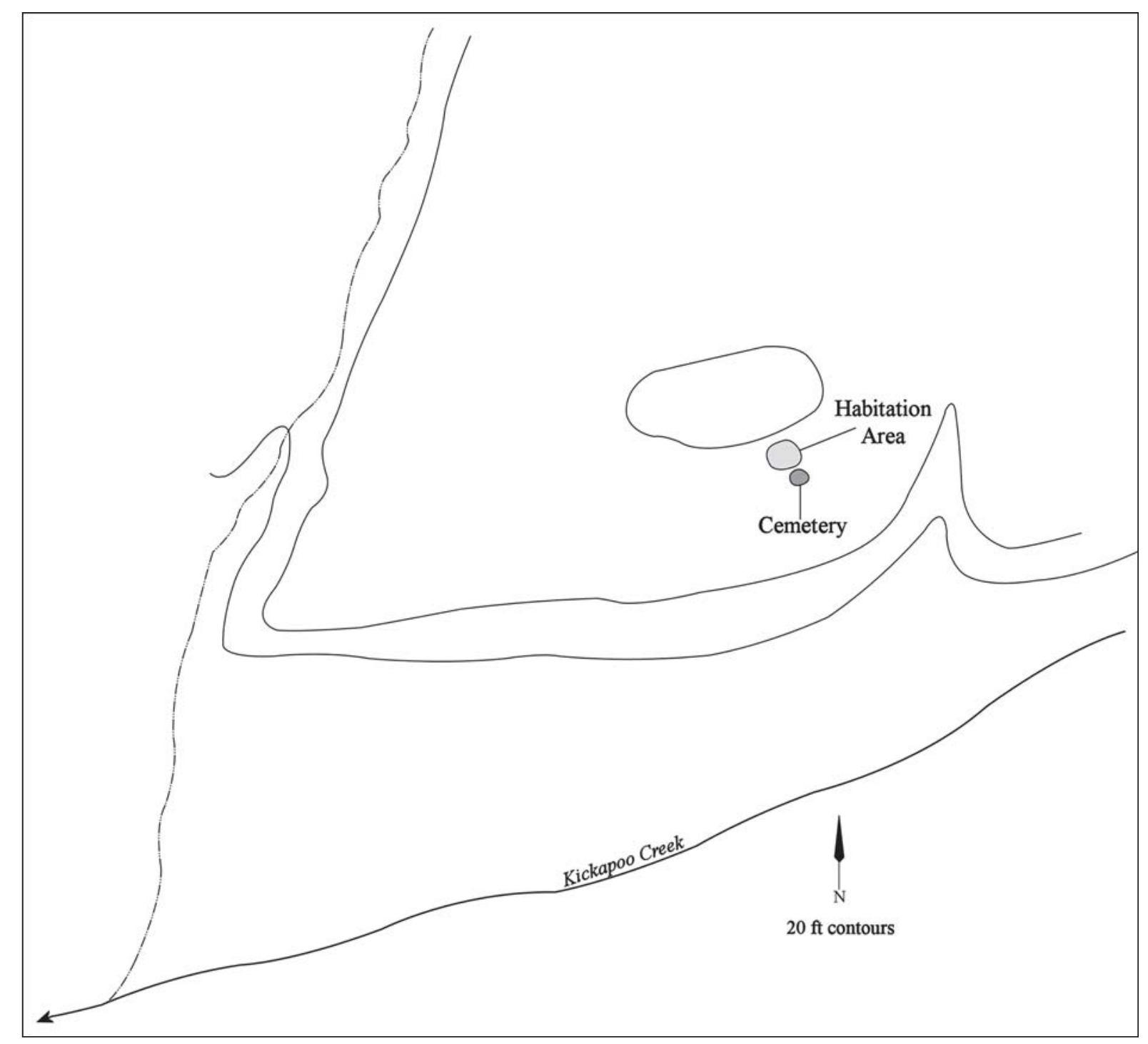

Figure 2. The topographic setting of 41SM150 in the Kickapoo Creek valley.

\section{Site Features}

According to the collectors that were working the site, there are two principal Caddo cultural features at 41SM150. The first is a ca. $60 \mathrm{~m}$ diameter habitation area, likely with midden deposits, and an adjacent cemetery (see Figure 2). The cemetery area was estimated at ca. $30 \mathrm{~m}$ in diameter, and at least 10 burials had been excavated there (Figure 3). The burial features were in three groups, based on their orientation and depth. The first group includes five closely-spaced burials in a general east-west row, with the graves oriented northeast-southwest, and ca. 1.5-2.5 feet in depth. The second group has two burials that are oriented east-west, and in deeper and overlapping graves (3-4.0 feet in depth). The last known group in the cemetery has three burials, in graves that ranged from 1.5-4.0 feet in depth; these graves are oriented east-northeast to west-southwest (Figure 3). Funerary offerings with these 10 burials included only ceramic vessels, a total of 54 vessels (a mean of 5.4 vessels per burial) being recovered in the burial assemblage. 


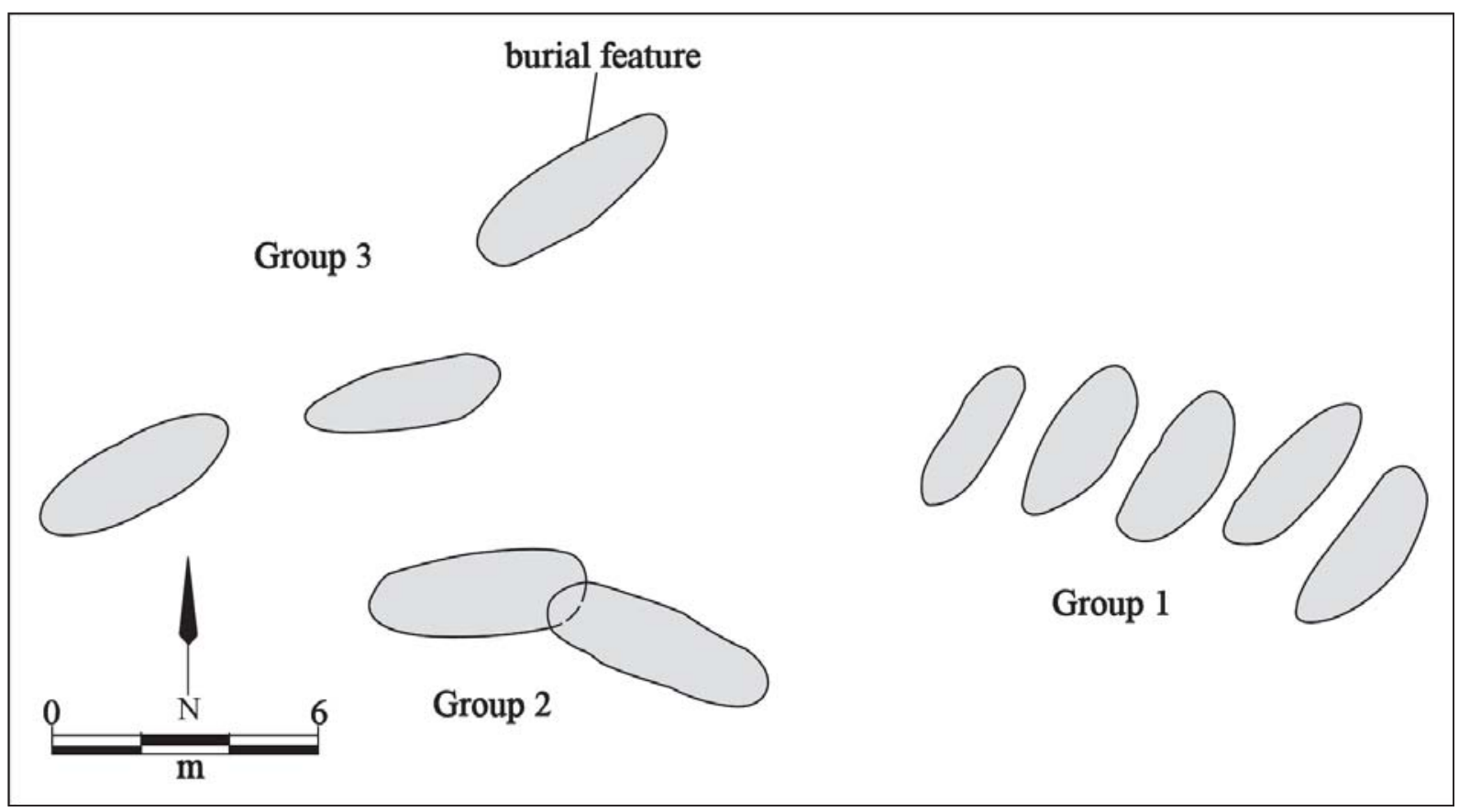

Figure 3. Plan of known burial features at 41SM150.

\section{Ceramic Vessels}

Jan Guy and Susan Lisk were able to document 15 of the vessels from the burial features at 41SM150 (Table 1), and they include bottles $(n=4)$, carinated bowls $(n=2)$, bowls $(n=2)$, one effigy bowl, compound bowls $(n=2)$, and jars $(n=4)$. The vessels are small to medium-sized, with volumes less than 1-2 liters. Where recorded, the vessels were most commonly tempered with grog $(n=4)$, grog-bone $(n=3)$, and bone $(n=1)$. It is not known which burials the vessels had been placed in as funerary offerings.

Table 1. Ceramic vessels documented from the burial features at 41SM150.

\begin{tabular}{llllll}
\hline Vessel No. & Vessel Form & $\begin{array}{l}\text { HT } \\
(\mathrm{cm})\end{array}$ & $\begin{array}{l}\text { OD } \\
(\mathrm{cm})\end{array}$ & $\begin{array}{l}\text { Th } \\
(\mathrm{mm})\end{array}$ & Decorative Method \\
\hline 1 & Bottle & 16.5 & 4.65 & 4.5 & Engraved \\
2 & Carinated Bowl & 5.6 & 16.5 & 7.0 & Engraved \\
3 & Carinated Bowl & 9.7 & 15.1 & 7.0 & Punctated-Noded; \\
& Strap handles & & & & \\
4 & Bottle & 17.0 & 4.8 & 5.5 & Engraved \\
5 & Effigy bowl & 7.1 & 14.8 & 6.0 & Engraved \\
6 & Jar & 10.7 & 9.4 & 5.3 & Incised-punctated \\
7 & Bottle & $6.8+$ & 7.3 & 5.0 & Engraved \\
8 & Jar & 12.6 & 11.5 & 5.8 & Incised-punctated \\
9 & Jar & 11.8 & 9.4 & 6.5 & Incised \\
10 & Jar & 14.6 & 12.7 & 6.5 & Incised-punctated \\
11 & Bowl & 8.8 & 15.2 & 8.5 & Punctated \\
12 & Bowl & 6.5 & 11.8 & 5.0 & Plain \\
13 & Compound Bowl & 7.6 & 16.4 & 7.0 & Incised-Punctated \\
14 & Bottle & 16.5 & 4.9 & 7.0 & Engraved \\
15 & Compound Bowl & 10.5 & 16.6 & 5.0 & Plain \\
\hline
\end{tabular}


Two of the vessels from 41SM150 are plain, one has a punctated decoration, another has punctated and noded elements, one jar has an incised decoration, four vessels (three jars and a compound bowl) have incised-punctated decorative elements, and six have engraved decorative elements (see Table 1). All of the bottles in the vessel assemblage are engraved, as is the one effigy bowl, the incised and incisedpunctated vessels are primarily jars, while the other vessels have a range of decorative elements.

Vessel 1 is a bottle with an engraved motif repeated four times around the vessel body (Figure 4). The engraved motif consists of interlocking scrolls that end in hooked arm elements, and there are also a series of diagonal cross-hatched lines that connect the scrolls.

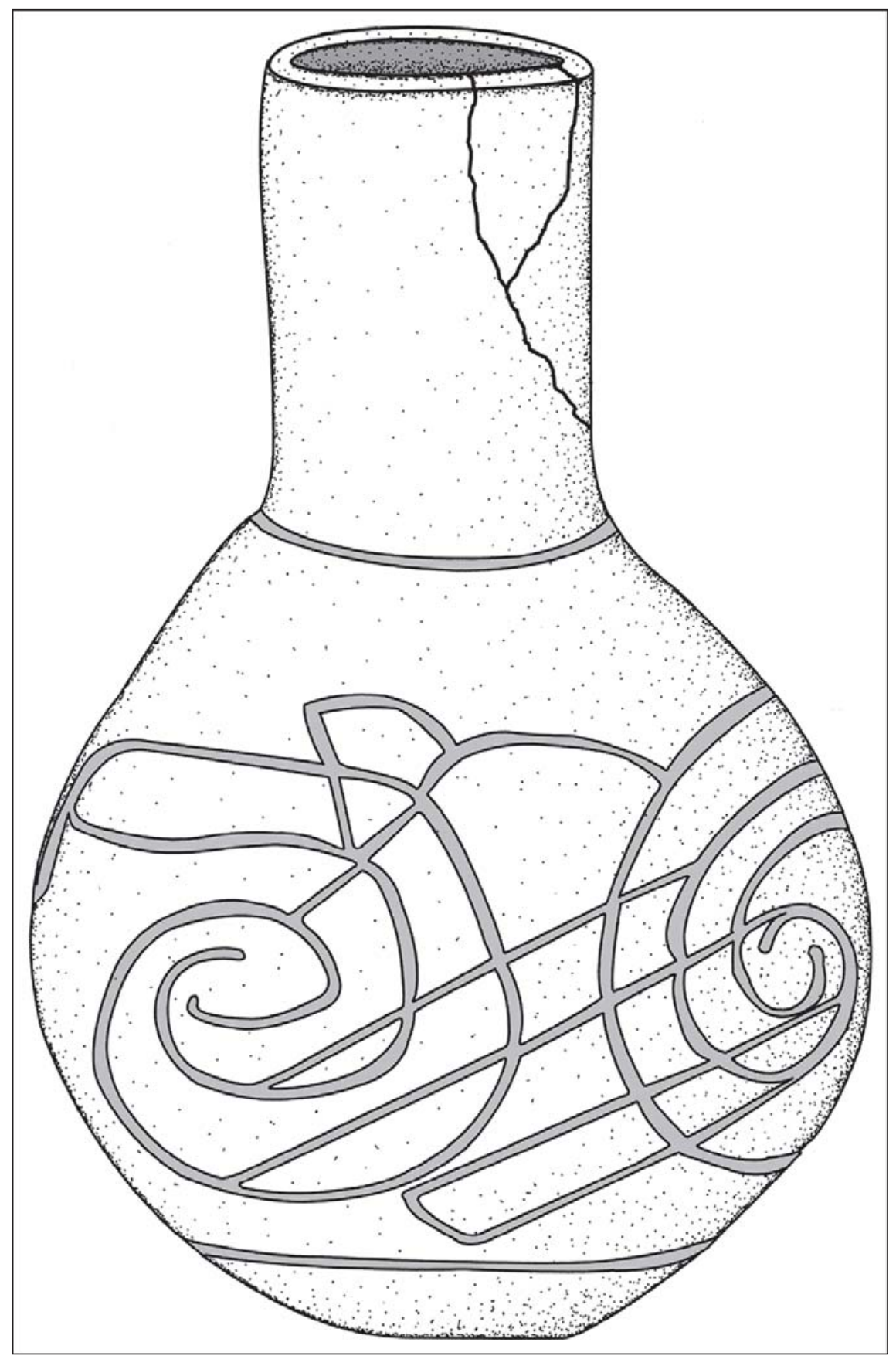

Figure 4. Vessel 1, engraved bottle. 
Vessel 2 in the assemblage is a carinated bowl with a scalloped lip (Figure 5). The rim panel has a series of rectilinear engraved scrolls with upward-pointing linear tick marks, as well as a single horizontal engraved line around the vessel that has downward-pointing linear tick marks.

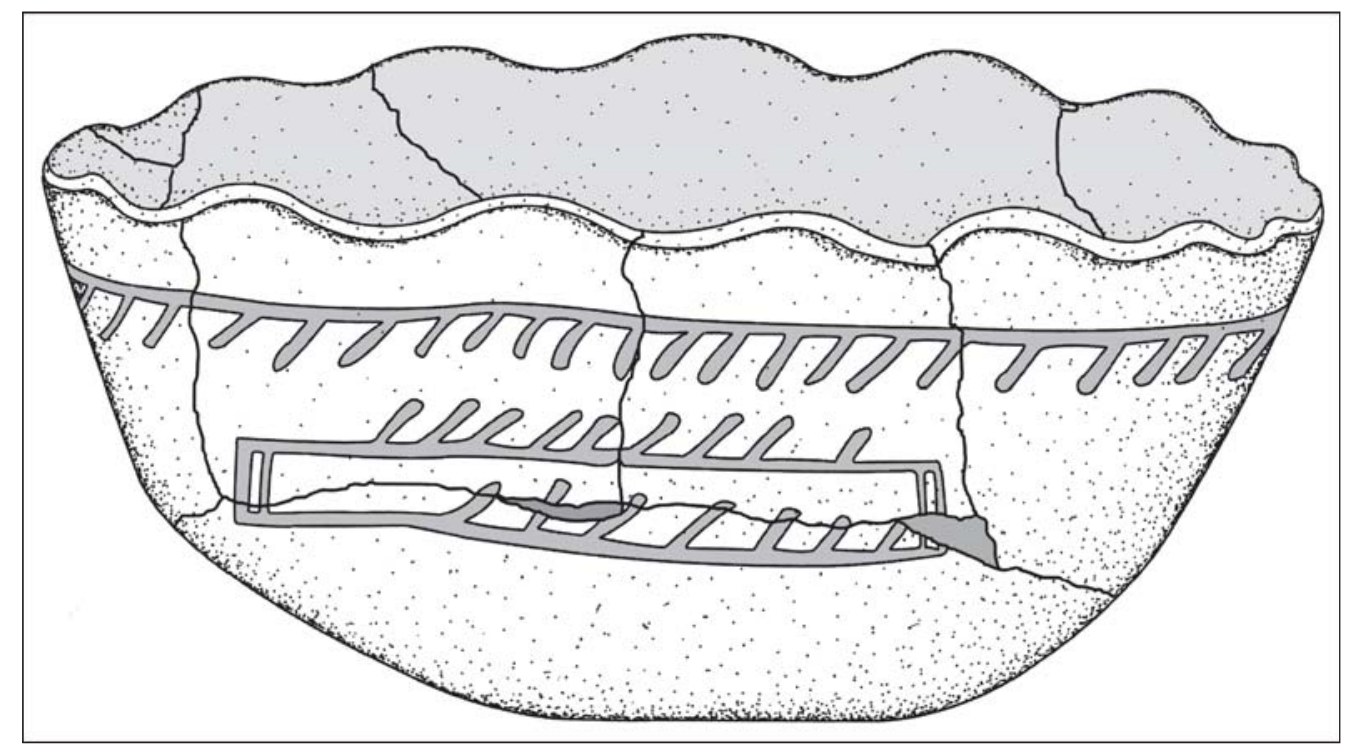

Figure 5. Vessel 2, engraved carinated bowl.

Vessel 3 is a Washington Square Paneled carinated bowl with large strap handles (Figure 6). The rim has two stacked panels decorated with incised brackets filled with tool punctations, and the panels themselves are outlined by horizontal rows of tool punctations. On the lower rim panel, there are centrallyplaced appliqued nodes in the oval-shaped areas between brackets (Figure 6). The strap handles extend from the upper to the lower rim panel, and the handles are decorated with a rectilinear pattern of tool punctations with a centrally placed appliqued node.

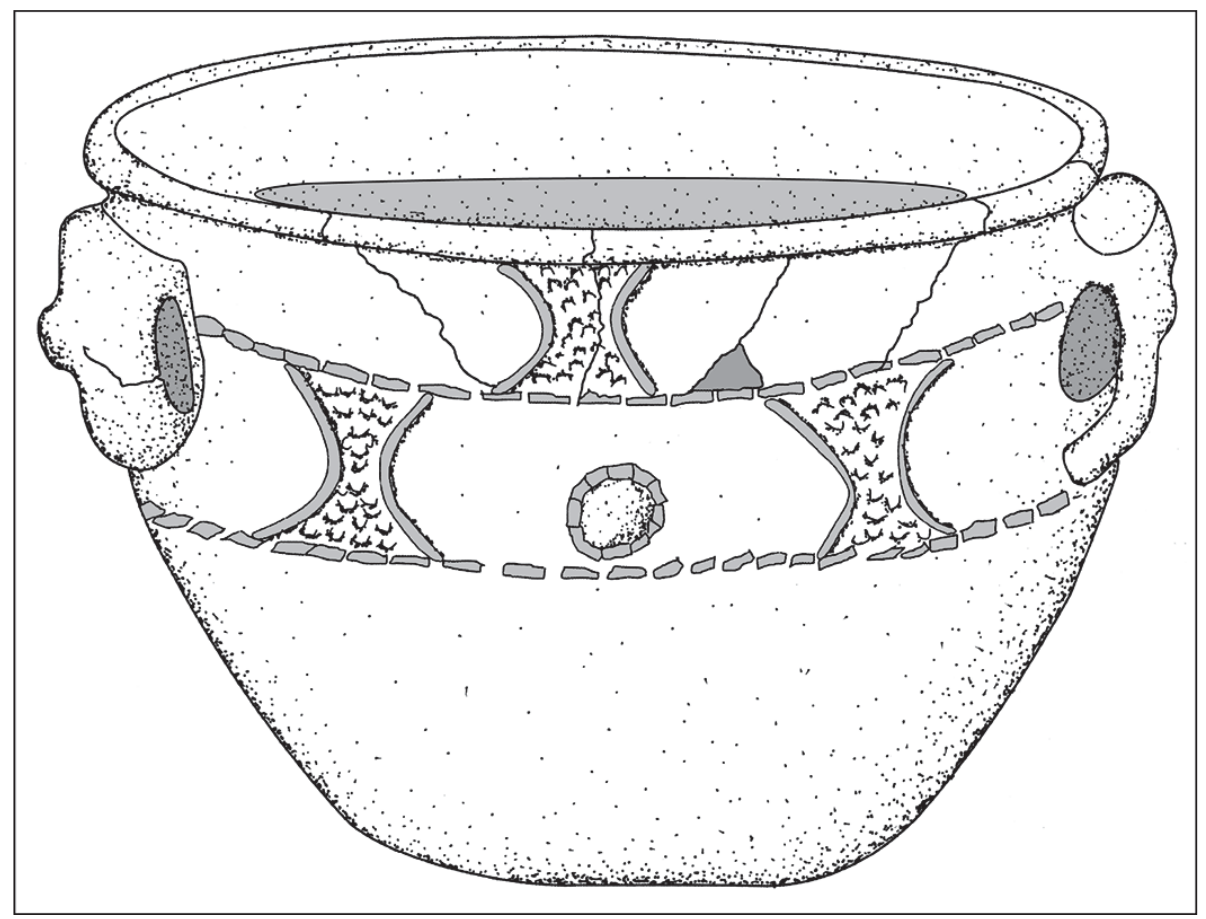

Figure 6. Vessel 3, punctated-noded carinated bowl. 
Vessel 4 is a Nacogdoches Engraved bottle with three sets of engraved circle and cross elements and lower or upper rectilinear bands with two sets of horizontal cross-hatched zones and a single curvilinear engraved line (Figure 7); the central circle element has multiple horizontal, vertical, or diagonal lines. These elements are separated by sets of two closely-spaced vertical engraved lines, and there is also a set of two or three closely-spaced horizontal engraved lines at the top of the circle-and cross elements as well as a single horizontal engraved line at the base of the bottle neck.

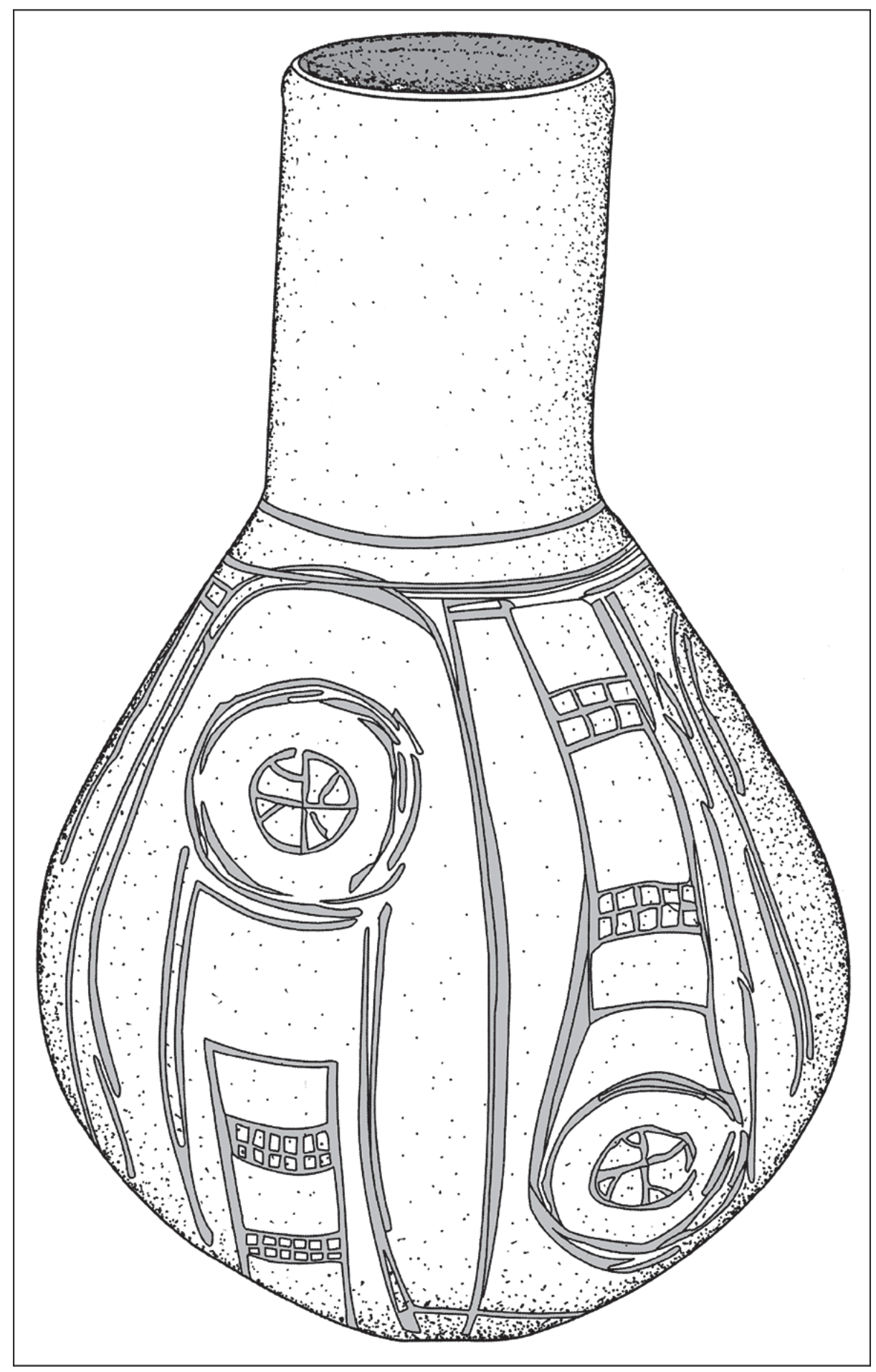

Figure 7. Vessel 4, engraved bottle. 
Vessel 5 in the 41SM150 vessel assemblage is a bird effigy bowl with four horizontal engraved lines on the upper part of the vessel (Figure 8). The lines curve upwards under the bird head and the tab tail attachment with two flanges (one broken off). There are two concentric engraved semi-circular lines on the surface of the tab tail, while engraved lines on the bird head itself define the head, eyes, and the beak. A similar bird effigy bowl was recovered in Feature 31 at the Washington Square Mound site (Perttula et al. 2010:Figure 32a-b).

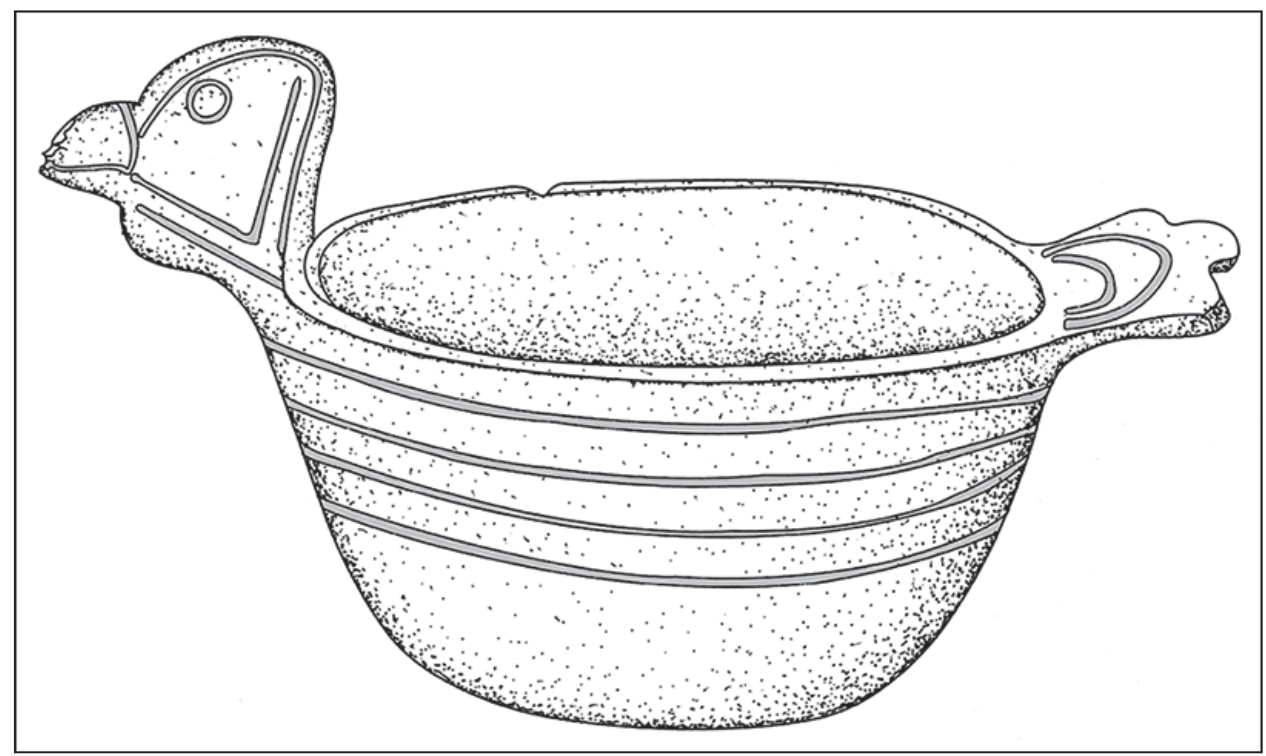

Figure 8. Vessel 5, engraved effigy bowl.

Vessel 6 is a utility ware cylindrical-shaped jar with an incised-punctated motif on the rim (Figure 9). The vessel is decorated with a series of incised triangle elements filled with rows of tool punctations. A single horizontal incised line defines the base of the motif.

Vessel 7 from 41SM150 is another Nacogdoches Engraved bottle; the neck is missing (Figure 10). The upper part of the vessel body has two closely-spaced horizontal engraved lines, while the remainder of the vessel body has a circle and cross motif repeated five times around the vessel; the outermost circle is defined by several closely-spaced circular lines. The cross elements in the innermost circle have excised triangles where they intersect the innermost circle lines. Connecting the repeated circle and cross motifs are a series of short horizontal engraved lines in bracket-shaped areas (Figure 10).

Vessel 8 is a cylindrical-shaped jar with an incised-punctated decoration. This consists of a band of randomly-placed tool punctations along the rim, underlain by a single horizontal incised

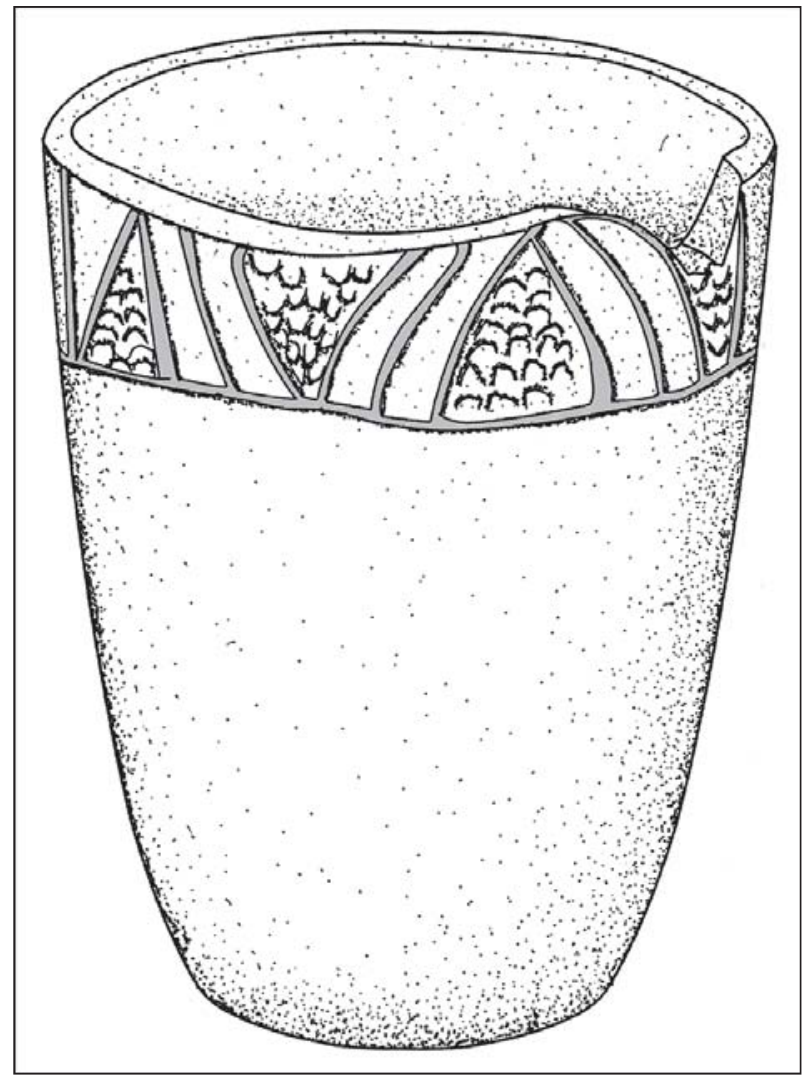

Figure 9. Vessel 6, incised-punctated jar. 


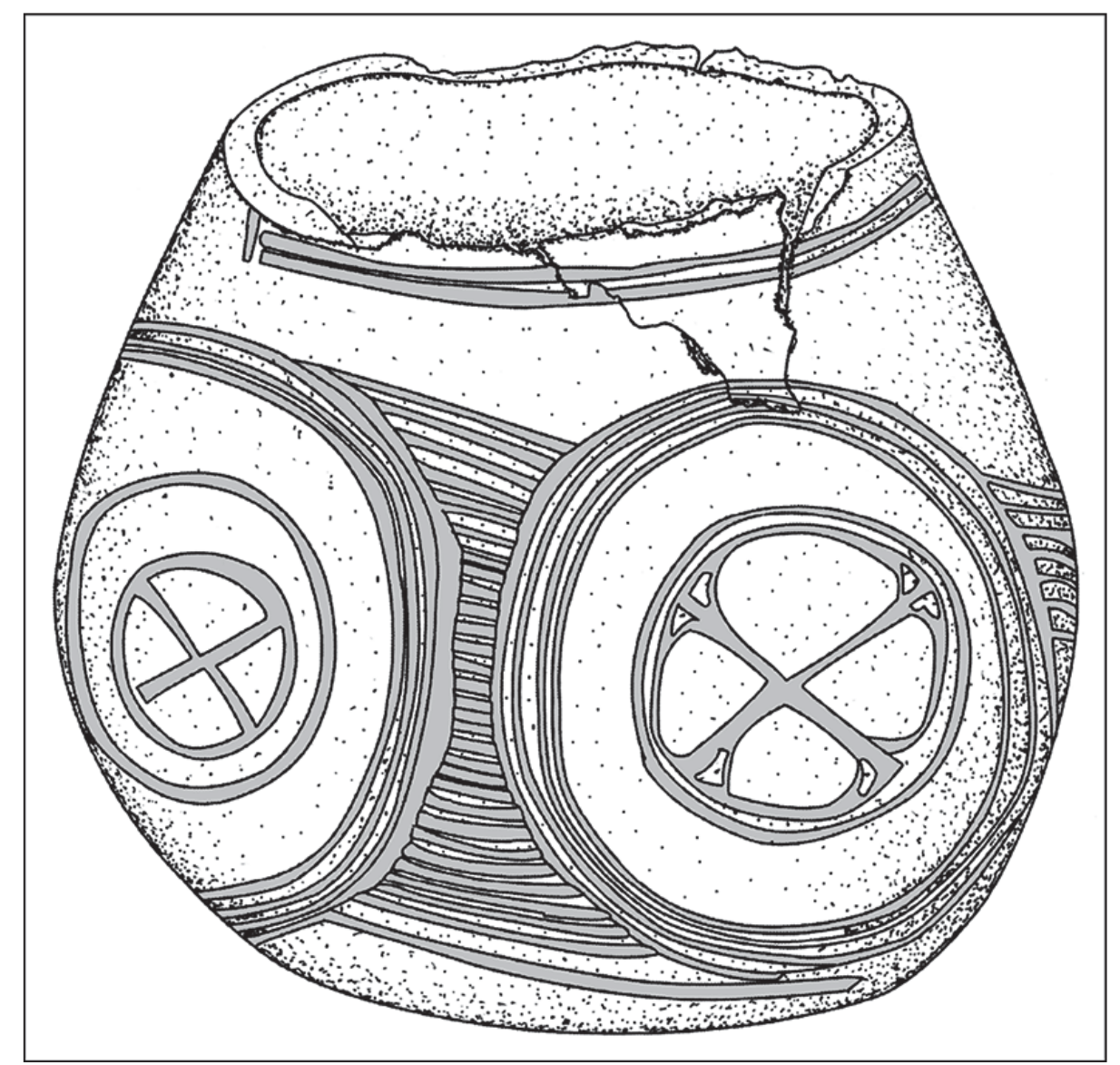

Figure 10. Vessel 7, engraved bottle.

line. There are extensive amounts of organic residue on the lower third of the jar, suggesting this was a cooking vessel. Vessel 9, probably a Maydelle Incised vessel, is a globular-shaped jar with an everted rim. It has cross-hatched incised lines on the rim, bordered by a single horizontal incised line at the rimbody juncture. Vessel 10 is also a globular jar with an everted rim. It has horizontal bands of tool punctations on the vessel rim, with a single horizontal incised line at the rim-body juncture.

Vessel 11 in the documented assemblage from 41SM150 is a bowl with randomly-spaced fingernail punctations covering the vessel surface. About 75 percent of the bowl is blackened by soot and organic residue. Vessel 12 is a plain bowl that has been smoothed on both interior and exterior surfaces.

Vessel 13 is a Washington Square Paneled compound bowl (Figure 11). Each panel is divided into oval-shaped zones by incised brackets filled with tool punctations. The top and bottom of the two panels are defined by horizontal rows of tool punctations.

Vessel 14 is a bottle with a poorly preserved engraved motif (Figure 12). What is apparent are curvilinear and semi-circular engraved lines, rectilinear elements, and a large triangular element with an inner circle defined by two closely-spaced circular lines. The triangular element may represent an elongated bird head with a circular eye.

The last of the documented ceramic vessels from 41SM150, Vessel 15 is a plain compound bowl (Figure 13). The vessel has an everted rim, and has been smoothed on both vessel surfaces. The shape of Vessel 15 is very much like Vessel 13 (see Figure 11), the other compound bowl in the assemblage. 


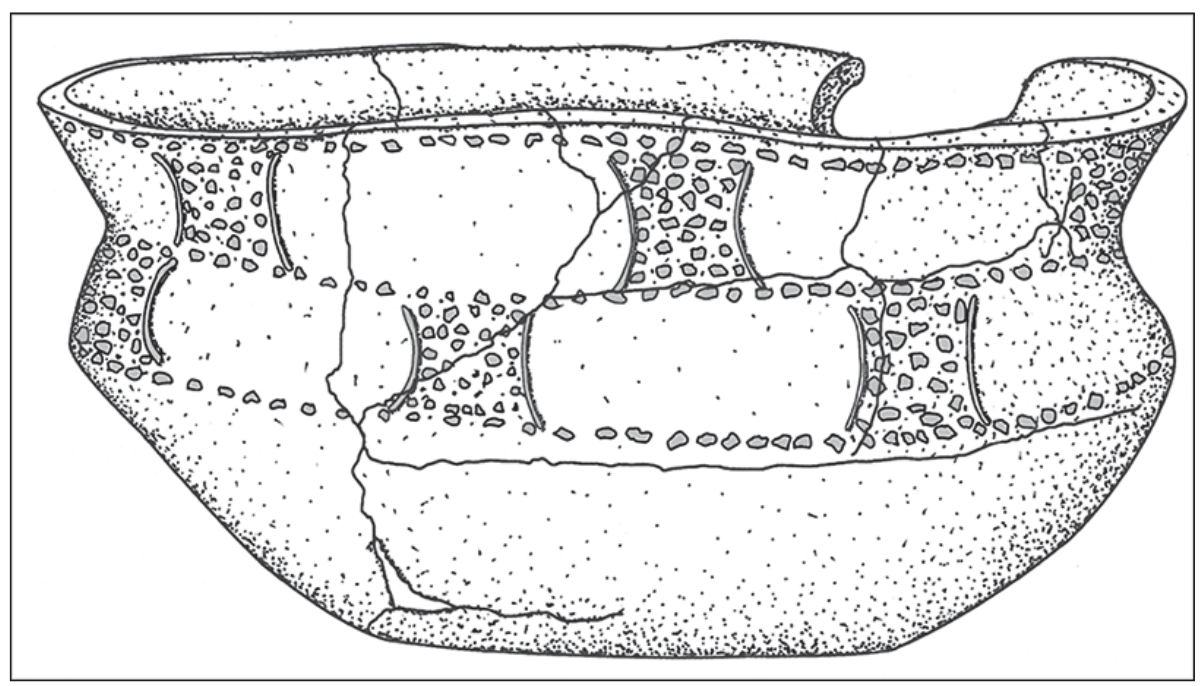

Figure 11. Vessel 13, incised-punctated compound bowl.

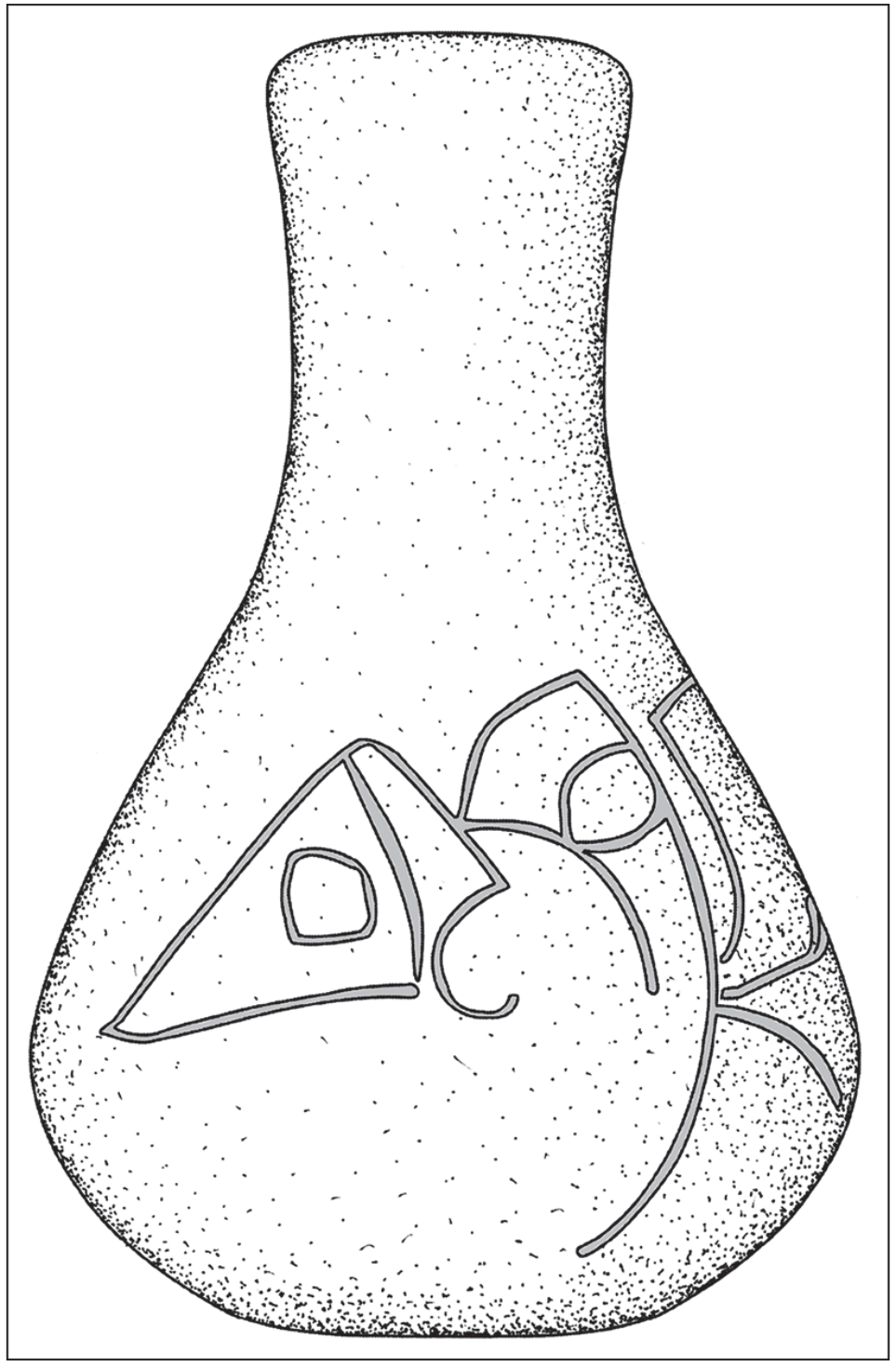

Figure 12. Vessel 14, engraved bottle. 


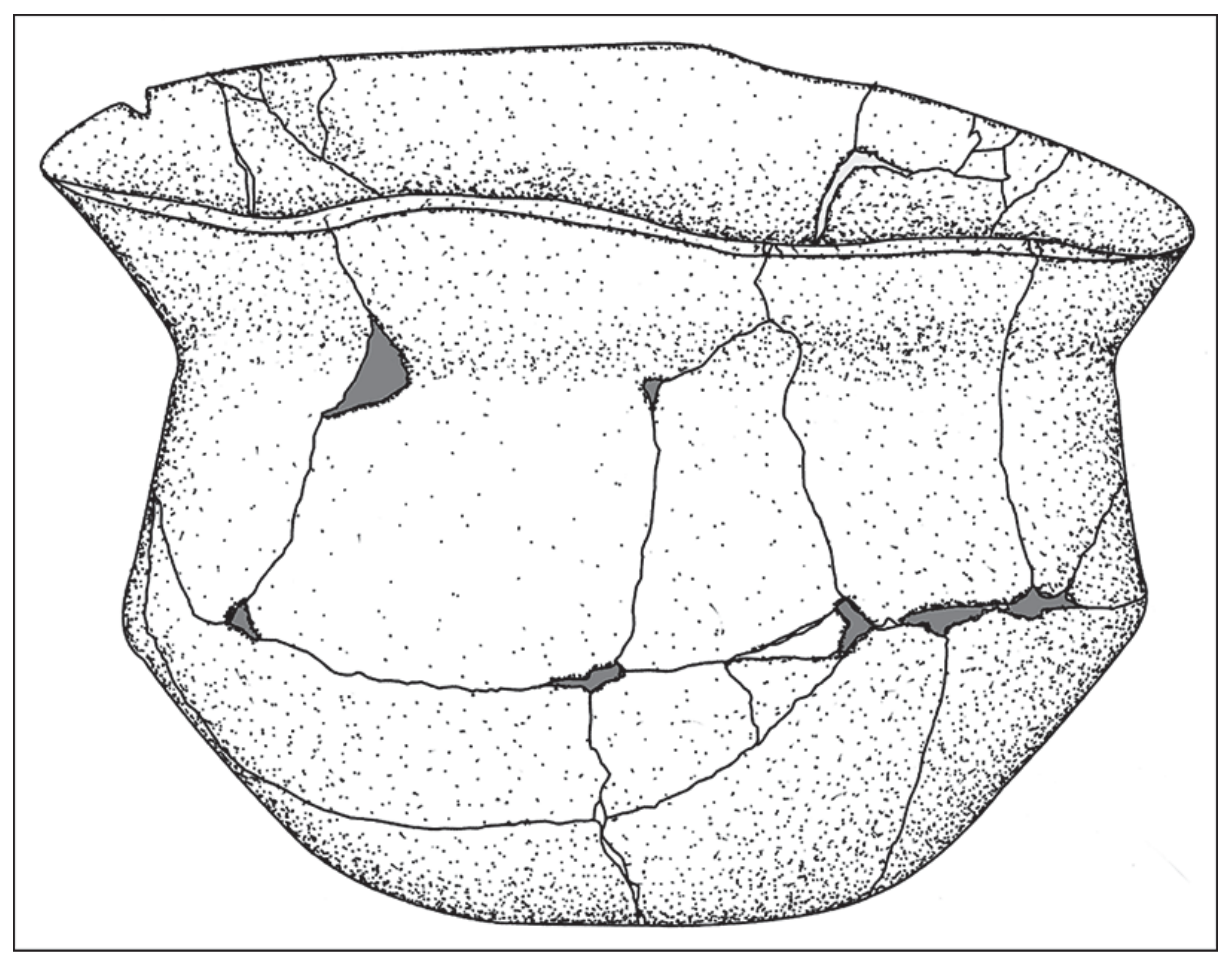

Figure 13. Vessel 15, plain compound bowl.

\section{Ceramic Vessel Sherds}

A small sample of ceramic vessel sherds $(n=23)$ were also documented from 41SM150, perhaps from as many as six different vessels. The nine decorated sherds included one Nacogdoches Engraved rim sherd (Figure 14a; see also Perttula et al. 2010:Figure 41), a triangular incised-zone punctated body sherd (Figure 14b; such decorative elements on utility ware vessels are abundant at the Washington Square Mound site and many other East Texas sites, see Hart [1982, 2014] and Perttula [2009:Figure 9]), four with brushed-punctated decorative elements (perhaps from Pease Brushed-Incised vessels), a brushedpinched sherd, and two sherds with brushing marks. The 14 undecorated sherds are represented by a rim, 10 body sherds (one possibly from a carinated bowl), and three conjoined base sherds that represent ca. 50-60 percent of a vessel base.

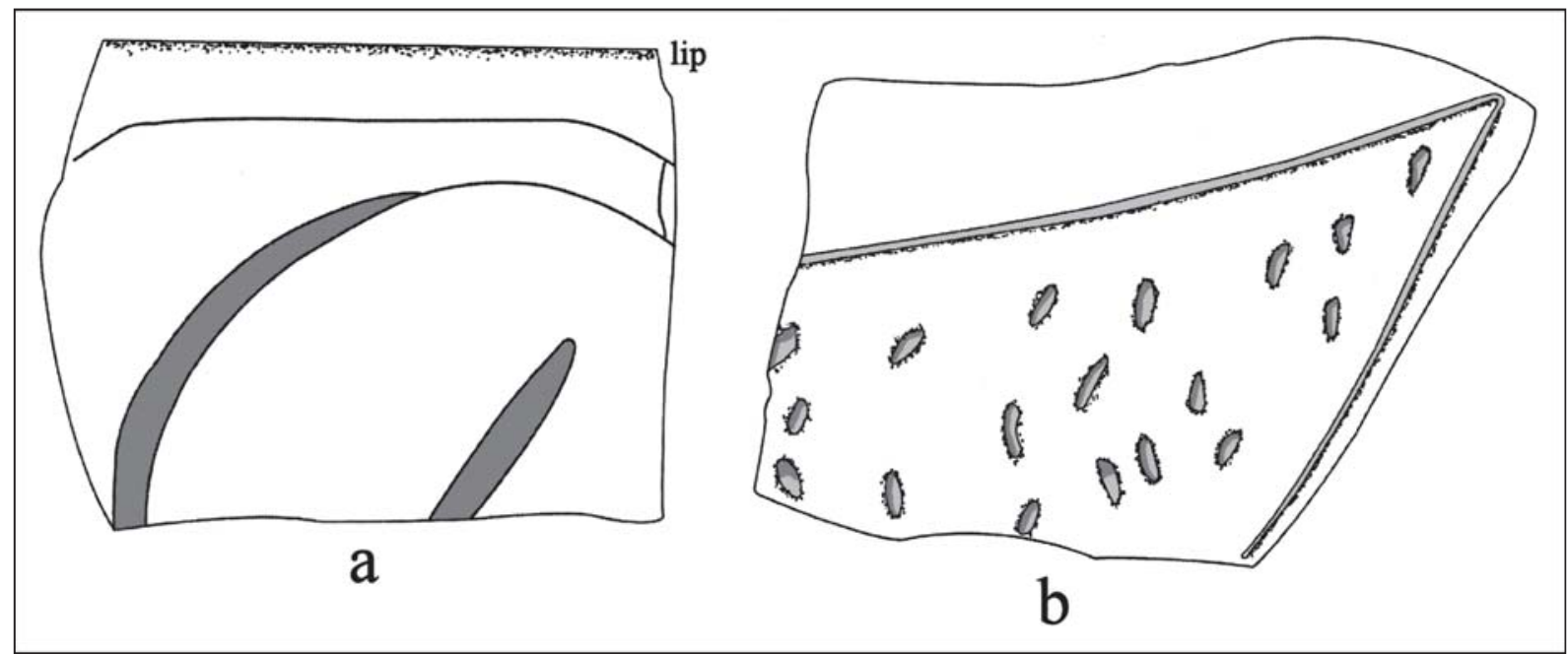

Figure 14. Selected decorative elements on sherds from 41SM150. 


\section{Ceramic Platform Pipe}

Also in the collection is about 50 percent of a ceramic platform pipe (Figure 15). The remnant of the plain platform pipe is $48 \times 37 \mathrm{~cm}$ in length and width, with a rounded platform and a centrally-placed bowl. The exterior diameter of the low bowl is $30 \mathrm{~mm}$.

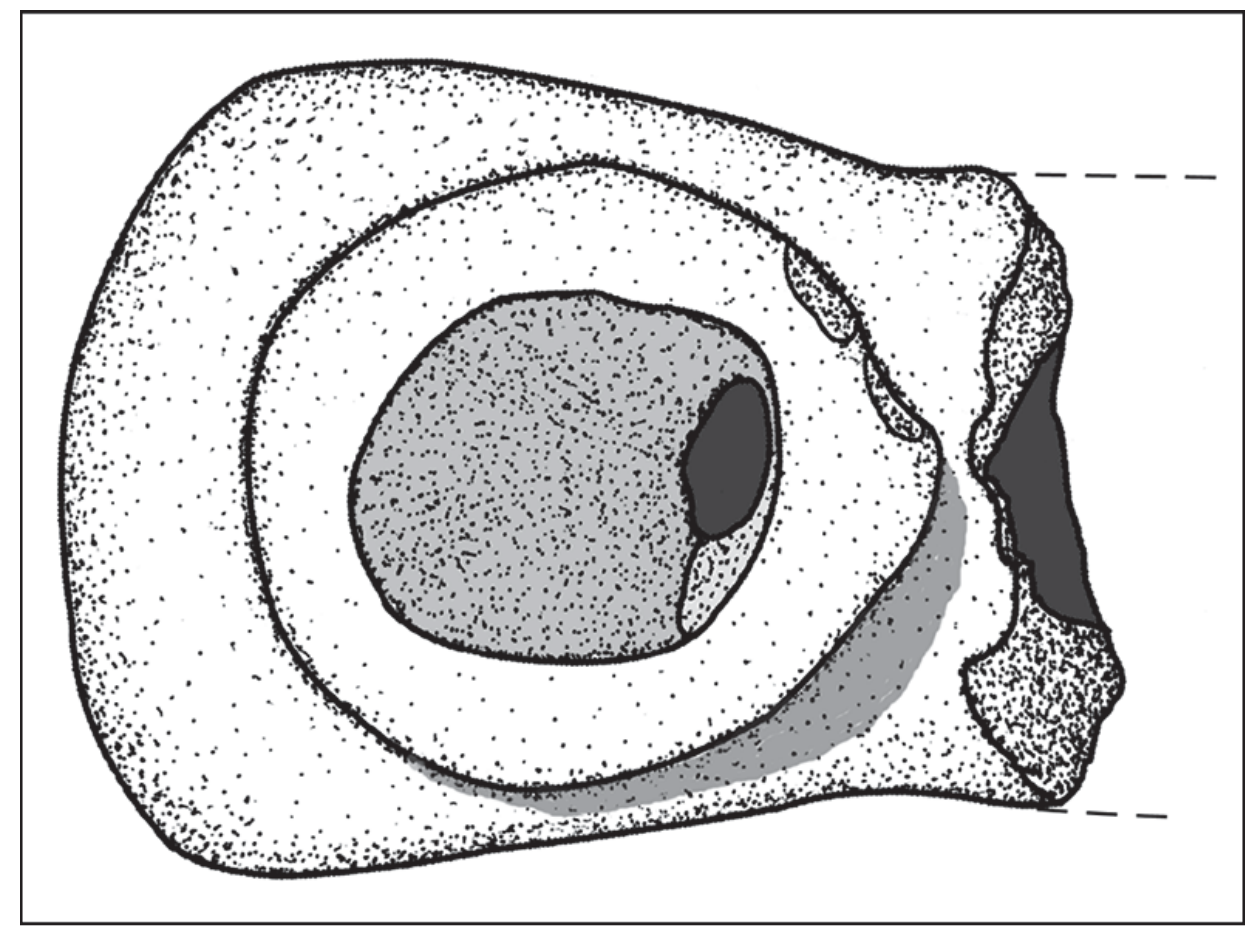

Figure 15. Ceramic platform pipe sherd from 41SM150.

\section{Summary and Conclusions}

Site 41SM150 is an ancestral Caddo habitation site and cemetery along Kickapoo Creek in the northern part of the Angelina River basin in East Texas. What little is known about the site comes from records and notes on file at the Texas Archeological Research Laboratory at The University of Texas at Austin (TARL) compiled by students in a 1983 field school directed by Dr. Dee Ann Story. At that time, the site had been dug for a number of years by several collectors, and they had recently exposed and dug a Caddo cemetery with 10 burial features; the cemetery was not far south from a small (less than 1.0 acre) habitation area with likely midden deposits.

These 10 burials had 54 ceramic vessels placed in the graves as funerary offerings. One of the collectors allowed his collection of vessels $(n=15)$, sherds $(n=23)$, and a platform pipe fragment to be documented by Story's field school students. This article is based on these TARL documentation notes and records.

The ceramic vessels include medium-sized plain ware, utility ware, and fine ware vessels, among them two Washington Square Paneled vessels, two Nacogdoches Engraved bottles, an engraved bird effigy bowl, and several incised-punctated jars. The vessels are tempered with grog and/or bone.

This ceramic assemblage is stylistically related to the Middle Caddo period mound and village component at the Washington Square Mound (41NA49) farther downstream in the Angelina River basin (Corbin and Hart 1998; Perttula et al. 2010), as well as to other sites in this basin as well as parts of the middle Sabine River basin that share several distinctive engraved motifs (Hart 1982, 2014; Perttula 
2013:192). Based on 12 radiocarbon dates from the Washington Square Mound site (Corbin and Hart 1998; Perttula 2016), it is likely that the Caddo occupation at 41 SM150 took place between ca. A.D. 1270-1440, during the Middle Caddo period.

\section{Acknowledgments}

It would have been impossible to prepare this article without the excellent records and notes compiled by Jan Guy in 1983; these records and notes are on file at the Texas Archeological Research Laboratory at The University of Texas at Austin. Lance Trask prepared the figures in the article.

\section{References Cited}

Corbin, J. E. and J. P. Hart

1998 The Washington Square Mound Site: A Middle Caddo Mound Complex in South Central East Texas. Bulletin of the Texas Archeological Society 69:47-78.

Hart, J. P.

1982 An Analysis of the Aboriginal Ceramics from the Washington Square Mound Site, Nacogdoches County, Texas. Master's thesis, Department of Anthropology, Northeast Louisiana University, Monroe.

2014 An Analysis of the Aboriginal Ceramics from the Washington Square Mound Site, Nacogdoches County, Texas. Stephen F. Austin State University Press, Nacogdoches.

Perttula, T. K.

2009 Analysis of the Caddo Archeological Materials from the 1985 Texas Archeological Society Field School at the Washington Square Mound Site, Nacogdoches County, Texas. Bulletin of the Texas Archeological Society 80:145-193.

2013 Caddo Ceramics in East Texas. Bulletin of the Texas Archeological Society 84:181-212.

2016 New Radiocarbon Dates from Ancestral Caddo Sites in Cherokee, Fannin, Hopkins, Nacogdoches, and Wood Counties, Texas. Journal of Northeast Texas Archaeology 67:1-5.

Perttula, T. K., M. Walters, B. Nelson, B. Gonzalez, and R. Cast, with a contribution by R. G. Franciscus 2010 Documentation of Associated and Unassociated Caddo Funerary Objects in the Stephen F. Austin State University Collections, Nacogdoches, Texas. Stephen F. Austin State University Press, Nacogdoches. 